\title{
Leptin modulates fertility under the influence of elevated growth hormone as modeled in oMt1a-oGH transgenic mice
}

\author{
A D Thomas ${ }^{1}$, J D Murray ${ }^{1,2}$ and A M Oberbauer ${ }^{1}$ \\ ${ }^{1}$ Department of Animal Science, University of California, One Shields Avenue, Davis, CA 95616, USA \\ ${ }^{2}$ Department of Population, Health, and Reproduction, School of Veterinary Medicine, One Shields Avenue, University of California, Davis, CA 95616, USA \\ (Requests for offprints should be addressed to A M Oberbauer; Email: amoberbauer@ucdavis.edu)
}

\begin{abstract}
Elevated growth hormone $(\mathrm{GH})$ concentrations suppress reproductive function in a variety of species, although it is unclear whether GH directly suppresses reproductive performance, or whether $\mathrm{GH}$ activates other pathways to achieve these effects. The ovine metallothionein 1a-ovine $\mathrm{GH}$ (oMt1a-oGH) transgenic mouse has been used to model the effects of $\mathrm{GH}$ on both body composition and reproductive function. A recent report has documented increased leptin levels in obese oMt1a-oGH mice. Given the importance of leptin in modulation of the reproductive endocrine axis, as well as the reports documenting reduced leptin signal transduction in animals with elevated leptin levels, we hypothesized that high leptin concentrations in response to elevated $\mathrm{GH}$ would reduce fertility. To determine the effects of high circulating leptin levels on the reproductive endocrine axis, we assessed hypothalamic neuropeptide Y (NPY) and GnRH expression. At weaning, oMt1a-oGH transgenic (TG) and wild-type (WT) female mice were allocated to one of four treatment groups: oMt1a-oGH females chronically expressing the transgene (TG ON); oMt1a-oGH females expressing the
\end{abstract}

transgene from 3 to 8 weeks of age (TG ON/OFF); WT females receiving the transgene stimulus from 3 to 8 weeks of age (WT ON/OFF); and WT females never receiving the transgene stimulus (WT OFF). Eight-week-old females were housed with males for a 2 -week period, after which females were isolated from males and allowed to carry pregnancies to term. Body and gonadal fat pad (GFP) weights, along with plasma leptin concentrations, estrous cyclicity, pregnancy rate and litter characteristics, were recorded for each female. Chronic expression of the oMt1a-oGH transgene resulted in larger leaner mice, and inactivation of the transgene produced obese females. Pregnancy rate was reduced in TG ON females when compared with all other groups, and infertility was associated with elevated leptin levels. In addition, high leptin levels were associated with increased NPY expression, suggesting reduced leptin-signaling capacity, which may contribute to suppression of the reproductive axis in oGH animals.

Journal of Endocrinology (2004) 182, 421-432

\section{Introduction}

High circulating growth hormone $(\mathrm{GH})$ concentrations in females result in decreased reproductive performance in mice (Murray \& Pomp 1995, Pomp et al. 1995, Thomas et al. 2001), humans (Jadresic et al. 1982) and livestock (McGuffey et al. 1991, Downer et al. 1993, Oldenbroek et al. 1993, Esteban et al. 1994, Buskirk et al. 1996, Chapula et al. 1996). It is still unclear whether elevated $\mathrm{GH}$ suppresses reproductive function directly or through an intermediary pathway.

The ovine metallothionein 1a-ovine GH (oMt1a-oGH) transgenic mouse model has been a useful tool for the study of $\mathrm{GH}$ effects on reproduction. While many of the $\mathrm{GH}$ transgenic constructs currently in use utilize promoters that constitutively drive expression of the $\mathrm{GH}$ transgene (Palmiter et al. 1983, Orian et al. 1989), the oMt1a promoter is regulated by provision or exclusion of $25 \mathrm{mM}$ $\mathrm{ZnSO}_{4}$ in the drinking water (Shanahan et al. 1989). Oberbauer et al. (1997) reported average plasma oGH concentrations of $2279 \mathrm{ng} / \mathrm{ml}$ in animals overexpressing the transgene, but inactivation of the transgene results in a drop in oGH concentrations to unstimulated levels within $24 \mathrm{~h}$ (Shanahan et al. 1989). The oGH females overexpressing the transgene are subfertile and unable to support implantation, despite the fact that normal blastocysts are observed at day 3.5 of pregnancy (Pomp et al. 1995).

Expression of the oGH transgene results in a lean phenotype, while transgene inactivation promotes accrual of adipose tissue and eventual obesity (Pomp et al. 1996, Oberbauer et al. 1997, Oberbauer \& Murray 1998). Oberbauer et al. (2001) reported significantly higher circulating leptin concentrations in oGH females with an inactivated oGH transgene than in mice chronically 
overexpressing oGH. This was attributed to larger adipose deposits in the former group. Many of the clinical problems documented in women with polycystic ovarian syndrome (PCOS) are exacerbated by obesity (Jacobs \& Conway 1999), and PCOS is often associated with increased leptin concentrations in subpopulations of affected women (Brzechffa et al. 1996). It was not until recently, however, that the link between body composition and reproduction was identified. The leptin (ob) gene cloned from white adipose tissue by Zhang et al. (1994) offered insight. Circulating leptin levels are proportional to the amount of energy stores contained within the body (Rosenbaum et al. 1996), and very high circulating leptin concentrations are associated with impaired reproductive function (Brzechffa et al. 1996). Collectively, these data suggest that leptin may play a role in suppressing reproductive function in obese individuals.

Under normal physiological conditions, leptin modulates neuropeptide Y (NPY) expression, which when chronically elevated suppresses fertility (Catzeflis et al. 1993, Pierroz et al. 1995). However, when circulating leptin levels are elevated, as seen in obese individuals, leptin signaling may be reduced (Campfield et al. 1995, 1996, Frederich et al. 1995, Halaas et al. 1997, Sinha \& Caro 1998). Arcuate NPY neurons contain glucocorticoid receptors (Cintra et al. 1991), and the presence of a glucocorticoid response element (GRE) in the promoter region of several mammalian NPY genes (Moore et al. 1985, Misaki et al. 1992) indicates the potential for glucocorticoids to stimulate NPY expression. oMt1a-oGH transgenic mice actively expressing the transgene have elevated plasma corticosterone concentrations (Thomas et al. 2001), suggesting that glucocorticoids may elevate NPY expression in these mice. Elevated NPY expression, then, could contribute to the reduced fertility observed in oMt1a-oGH mice. In infertile oMt1a-oGH females, reduced leptin signal transduction may attenuate the ability of leptin to downregulate NPY, resulting in suppression of gonadotropin-releasing hormone $(\mathrm{GnRH})$ release, gonadotropin release and reproductive function.

Previous reproductive studies utilizing oMt1a-oGH mice have evaluated females mated at 8-12 weeks of age (Murray \& Pomp 1995, Pomp et al. 1995, Thomas et al. 2001) when differences in body composition and leptin concentrations are just becoming pronounced between groups experiencing various elevated $\mathrm{GH}$-exposure regimens (Oberbauer et al. 2001). However, studies correlating reproductive function with body composition data, GH effects and leptin have not been done. The objective of this study was to elucidate the endocrine mechanism(s) by which the somatotropic axis affects adipose metabolism and reproductive function. The first specific aim was to characterize fertility as a function of transgene status, body composition and circulating leptin concentrations. The second aim was to correlate leptin levels with hypothalamic NPY and GnRH expression in order to assess the impact of varying levels of leptin on the reproductive endocrine axis.

\section{Materials and Methods}

\section{Animals}

The transgenic mice used in this study were produced by crossing mice homozygous for the oMt1a-oGH construct (Shanahan et al. 1989) in a CCX (C57/B16 x CBA) background to CCX wild-type (WT) mice. The resulting offspring were hemizygous for the transgene. WT cohorts were derived from CCX by CCX crosses. At 9-11 days of age, all female mice were toe-notched for identification purposes. At 3 weeks of age, females were weaned and allocated into one of four treatment groups: transgenic mice continuously overexpressing the $\mathrm{GH}$ transgene from 3 weeks of age (TG ON, $n=182$ ); transgenic mice expressing high levels of $\mathrm{GH}$ from 3-8 weeks of age (TG ON/OFF, $n=193$ ); WT mice receiving the transgene stimulus from 3-8 weeks of age but not expressing high GH levels (WT ON/OFF, $n=197$ ); and WT mice not receiving the transgene stimulus (WT OFF, $n=202$ ); the last two groups express normal levels of murine GH. Mice had free access to food (Purina Mouse Chow 5001, St Louis, MO, USA) and drinking water. Transgene expression was induced by inclusion of $25 \mathrm{mM} \mathrm{ZnSO}_{4}$ (Sigma Chemical Inc., St Louis, MO, USA) in the drinking water; GH levels in the transgenics decrease to peak WT levels within $24 \mathrm{~h}$ after removal of the zinc stimulus (Shanahan et al. 1989). Animals were housed under controlled conditions of photoperiod ( $14 \mathrm{~h}$ light: $10 \mathrm{~h}$ dark), humidity (55\%) and temperature $\left(65-70{ }^{\circ} \mathrm{F}\right)$ in an Association for Assessment and Accreditation of Laboratory Animal Care (AAALAC)-approved animal facility in accordance with NIH guidelines for animal care.

\section{Experiment 1}

Body weights were recorded weekly from weaning to completion of the experiment. At 15, 20, 25, 30, 35 or 40 weeks of age, a subset of females $(n=30)$ from each treatment group was placed with males of proven reproductive performance for 14 days. During this time, females were assessed daily for the presence of a vaginal copulatory plug. Females were isolated from males after the mating period. Pregnant females were allowed to maintain pregnancies to term, after which time pups were immediately removed from the dam. Reproductive data collected included total number of copulatory plugs observed, pregnancy rate and pregnancy characteristics, including gestation length and number of live and dead pups produced. Mice failing to produce litters were determined to be cycling if they demonstrated two periods of proestrus, punctuated by a period of diestrus. Proestrus was confirmed by the presence of epithelial cells, and diestrus by the presence of leukocytes in the vaginal smear. 
Table 1 Sequence of PCR primers and real-time TaqMan probes specific for murine GAPDH, NPY and GnRH

\begin{tabular}{|c|c|c|c|c|}
\hline & Primer name & Sequence $\left(5^{\prime} \rightarrow 3^{\prime}\right)$ & TaqMan probe name & Sequence $\left(5^{\prime} \rightarrow 3^{\prime}\right)$ \\
\hline $\begin{array}{l}\text { Target } \\
\text { GAPDH }\end{array}$ & $\begin{array}{l}\text { mGAPDH-167f } \\
\text { mGAPDH-263r }\end{array}$ & $\begin{array}{l}\text { GCACAGTCAAGGCCGAGAAT } \\
\text { GCСТCACСССАTTTGATGTT }\end{array}$ & mGAPDH-217p & АССАТСТTCСАGGAGCGAGACCCCA \\
\hline NPY & $\begin{array}{l}\text { mNPY2-165f } \\
\text { mNPY2-247r }\end{array}$ & $\begin{array}{l}\text { CATCAATCTCATCACCAGACAGAGAT } \\
\text { TGCTTTCСТTCATTAAGAGGTCTGA }\end{array}$ & mNPY2-192p & TGGCAAGAGATCCAGCCCTGAGACA \\
\hline $\mathrm{GnRH}$ & $\begin{array}{l}\text { mGnRH-13f } \\
\text { mGnRH-89r }\end{array}$ & $\begin{array}{l}\text { CTGATGGCCGGCATTCTACT } \\
\text { GGGCGCAACCCATAGGA }\end{array}$ & $m G n R H-34 p$ & GGAGCAGCCTTCCAAACACACAGTCAG \\
\hline
\end{tabular}

Females were weighed and killed by $\mathrm{CO}_{2}$ asphyxiation 14 days after parturition. Mice failing to produce litters were killed at a comparable age. Blood was collected by cardiac puncture, and the right gonadal fat pad (GFP) dissected from the carcass and weighed for later correlation to plasma leptin levels and final body weight. The GFP is highly correlated with overall body fat content and can be used as an indicator of total body lipid (Rogers \& Webb 1980, Eisen \& Leatherwood 1981). Blood was transferred to EDTA tubes (Fisher Scientific, Santa Clara, CA, USA) and centrifuged at $1800 \mathrm{~g}$ for $20 \mathrm{~min}$, and plasma was collected and stored at $-70{ }^{\circ} \mathrm{C}$. Plasma leptin concentrations were measured by ${ }^{125} \mathrm{I}$ radioimmunoassay kit according to instructions provided by the manufacturer (Linco Research, St Charles, MO, USA).

\section{Experiment 2}

A decline in reproductive performance was observed in females mated at 40 weeks when compared with those mated at earlier ages. Therefore, further reproductive studies were undertaken to elucidate the causes for reduced fertility. Elevated leptin concentrations were associated with infertility in the previous experiment, and as leptin is known to modulate NPY expression, which in turn modulates the reproductive endocrine axis, we also assessed hypothalamic NPY and GnRH expression as a function of leptin concentrations and transgene activation status.

At either 15 or 40 weeks of age, females from each treatment group were placed with males of proven reproductive performance for 14 days, and treated as in the previous experiment. At 14 days after parturition, or at a comparable time point in infertile animals, females were killed by $\mathrm{CO}_{2}$ asphyxiation, and brain tissue was dissected and processed for either the real-time PCR or in situ hybridization procedures. The stage of the estrous cycle at time of death was assessed in order to ensure basal measurements of hypothalamic NPY and GnRH expression, and to avoid the transient increases in NPY and GnRH expression that occur during proestrus and estrus (Suzuki et al. 1995). Therefore, only animals demonstrating diestrus or metestrus on the day of death were assessed for hypothalamic NPY and GnRH mRNA expression. Blood was collected by cardiac puncture, and plasma leptin levels were determined. Plasma leptin concentrations were measured by ${ }^{125} \mathrm{I}$ radioimmunoassay kit (Linco). The intra-assay and interassay coefficients of variation were $2.57 \%$ and $6 \cdot 01 \%$ respectively. The detection limit of the assay was $0.86 \mathrm{ng} / \mathrm{ml}$.

\section{Real-time PCR}

Real-time PCR was used to quantitate hypothalamic NPY and GnRH expression. Briefly, following blood collection, mice were decapitated and the brain was removed. The hypothalamus was excised within 2-3 min of death according to anatomical landmarks; it is bounded by the optic chiasm anteriorly, the mamillary bodies posteriorly and the floor of the third ventricle dorsally (Zeman \& Innes 1963). Hypothalamic tissue was then snap frozen in liquid nitrogen, and stored at $-70{ }^{\circ} \mathrm{C}$ until RNA extraction.

One 20-40 mg piece of hypothalamic tissue per animal was placed in a tube with liquid nitrogen and pulverized with a mortar and pestle. Total RNA was extracted from the samples, according to the manufacturer's directions for the RNeasy Mini Kit (Qiagen). RNA was eluted with nuclease-free water into tubes previously treated with RNase-free DNase I (Fisher, Santa Clara, CA, USA) to eliminate contaminating genomic DNA. Samples were heated for $5 \mathrm{~min}$ at $95^{\circ} \mathrm{C}$ and then cooled on ice.

Synthesis of cDNA was achieved by adding RNA to a reverse transcriptase reaction consisting of $5 \times$ first-strand buffer (Invitrogen, Carlsbad, CA, USA), $10 \mathrm{mM}$ dNTPs, 0·1 M DTT, $40 \mathrm{U} / \mu \mathrm{l}$ RNaseOut (Invitrogen), $200 \mathrm{U} / \mu \mathrm{l}$ SuperScript II (Invitrogen), and $300 \mathrm{ng} / \mu \mathrm{l}$ random hexamers (Promega). The reaction was incubated at $42{ }^{\circ} \mathrm{C}$ for $50 \mathrm{~min}$, heat inactivated for $5 \mathrm{~min}$ at $95^{\circ} \mathrm{C}$, cooled on ice, and stored at $-20{ }^{\circ} \mathrm{C}$ until use.

For each target gene, two primers and an internal, fluorescent-labeled TaqMan probe $\left(5^{\prime}\right.$ end, reporter dye FAM (6-carboxyflourescein), 3' end, quencher dye TAMRA (6-carboxytetramethylrhodamine)) were designed, using Primer Express software (Applied Biosystems, Foster City, CA, USA) (Table 1). As an 
endogenous control, a real-time PCR system was designed to target murine glyceraldehyde-3-phosphate dehydrogenase (GAPDH). The length of the PCR products was restricted to very short fragments $(73-170 \mathrm{bp}$ ) to enable high amplification efficiencies.

Each $12 \mu \mathrm{l}$ PCR reaction contained $400 \mathrm{nM}$ of each primer, $80 \mathrm{nM}$ of the real-time probe, a commercially available PCR mastermix (TaqMan Universal PCR Mastermix, Applied Biosystems) containing $10 \mathrm{mM}$ TrisHCL (pH 8.3), $50 \mathrm{mM} \mathrm{KCl}, 5 \mathrm{mM} \mathrm{MgCl}, 2.5 \mathrm{mM}$ deoxynucleotide triphosphates, 0.625 U AmpliTaq Gold DNA polymerase per reaction, $0 \cdot 25 \mathrm{U}$ AmpErase UNG per reaction, and $5 \mu \mathrm{l}$ diluted cDNA sample. The samples were placed in 96-well plates and amplified in an automated fluorometer (ABI PRISM 7700 Sequence Detection System, Applied Biosystems). Amplification conditions were $2 \mathrm{~min}$ at $50{ }^{\circ} \mathrm{C}, 10 \mathrm{~min}$ at $95^{\circ} \mathrm{C}, 40$ cycles of $15 \mathrm{~s}$ at $95^{\circ} \mathrm{C}$ and $60 \mathrm{~s}$ at $60{ }^{\circ} \mathrm{C}$. Final quantitation was done by the comparative $\mathrm{C}_{\mathrm{T}}$ method (User Bulletin no. 2, Applied Biosystems) and is reported as relative transcription relative to a calibrator cDNA. In brief, the signal of the endogenous control GAPDH was used to normalize the target gene signals of each sample. The difference in the $\mathrm{C}_{\mathrm{T}}$ for the target and the $\mathrm{C}_{\mathrm{T}}$ for the internal control, termed $\Delta \mathrm{C}_{\mathrm{T}}$, was calibrated against a control group. The relative linear amount of target molecules relative to the calibrator, was calculated by $2^{-\Delta \Delta \mathrm{Ct}}$. Therefore, all target gene transcription is expressed as an $\mathrm{n}$-fold difference relative to expression in the calibrator group.

\section{In situ hybridization}

The in situ procedure was undertaken to confirm the NPY and GnRH expression data from the real-time PCR. Animals in either diestrus or metestrus on the day of death were assessed for hypothalamic NPY or GnRH expression. Within moments of death, brains were dissected free of the skull, and two transverse cuts at the level of the optic chiasm and mamillary bodies were employed in order to generate a coronal brain section encompassing the hypothalamus. These sections were placed, cerebellumside down, in cryomolds, which were then filled with embedding media and frozen with a combination of isopentane and liquid nitrogen. A beaker of isopentane was suspended in a container of liquid nitrogen to facilitate cooling of the isopentane. Specimens were then immersed in the cold isopentane until frozen. Frozen sections were stored at $-80^{\circ} \mathrm{C}$ until sectioning. Coronal brain sections were cut at $14 \mu \mathrm{m}$ through both the arcuate nucleus and the medial preoptic area with a cryostat and thawmounted onto poly-L-lysine-coated microscope slides (Electron Microscopy Services, Fort Washington, PA, USA). Sections were fixed in $4 \%$ paraformaldehyde and stored in $95 \%$ ethanol at $4{ }^{\circ} \mathrm{C}$ until use.

The in situ hybridization procedure was performed using oligonucleotides (Operon, Alameda, CA, USA) synthesized to recognize unique coding sequences in the genes of interest. The specific probes used were anti-sense NPY (5' GAGTAGTATCTGGCC ATGTCCTCTGC TGGCGCGTCCTCGCCCGG 3') (Guan et al. 1998) and anti-sense GnRH (5' TTCAGTGTTTCTCTTTC CCCCAGGGCGCAACCCATAGGACCAGTGCTG 3') (Fueshko et al. 1998). Sense probes were also generated as controls. Probes were end-labeled with $\left[\alpha^{33} \mathrm{P}\right]$ dATP (New England Nuclear, Boston, MA, USA), using terminal transferase (Boehringer-Mannheim, Indianapolis, IN, USA). Hybridization and washing conditions were as described by Wisden and Morris (1994). Briefly, a diluted radiolabeled probe was applied to each slide and incubated overnight at $42{ }^{\circ} \mathrm{C}$. Sections were then subjected to a series of 1 SSC and ethanol washes and allowed to air dry for $30 \mathrm{~min}$. Tissue sections and the appropriate controls were then exposed to the same film (Amersham Hyperfilm; one film for NPY and one film for GnRH) for 3 weeks and then developed. For NPY, the arcuate hybridization area was calculated with SigmaScan Pro (SPSS Inc., Chicago, IL, USA). Anatomical localization was verified with a mouse brain atlas (Montemurro \& Dukelow 1972).

\section{Statistical analysis}

Body weight, adipose, reproductive traits, and hypothalamic NPY and GnRH expression were analyzed by least-squares analysis of variance procedures for unequal subclass numbers, using PROC GLM of SAS (version $8 \cdot 0$ 2001). In addition, Pearson coefficients were calculated to determine the correlation between plasma leptin and body weight, leptin and GFP weight, and final body weight and GFP weight in experiment 1.

\section{Results}

\section{Experiment 1}

Body composition A time 2 weeks after parturition (5-7 weeks after mating) was chosen to collect body weight, adipose weight, and plasma leptin concentrations, as this allowed the mice to return to pre-pregnancy body weight and circulating leptin values. In addition, assessing leptin concentrations at this time also eliminated the confounding factors of pregnancy and lactation when comparing fertile and infertile females. Infertile animals, that is, those that failed to maintain a pregnancy, were assessed at a comparable age.

The WT ON/OFF and WT OFF groups were statistically equivalent in both the body composition $(P>0 \cdot 12)$ and reproductive $(P>0 \cdot 31)$ analyses; therefore, these groups were pooled for all analyses unless otherwise noted. Body weight, as expected, differed between the genoytpe classes and was a function of age as well 
Table 2 Pearson coefficient $\left(r^{2}\right)$ for correlation between leptin and body weight, leptin and right gonadal fat pad weight, and body weight and right gonadal fat pad weight for transgenic females chronically expressing the transgene (TG ON) or from 3-8 weeks of age (TG ON/OFF), and pooled wild-type (WT) females

\begin{tabular}{lllll} 
& $\begin{array}{l}\text { Leptin vs body } \\
\text { weight }\left(\mathbf{r}^{2}\right)\end{array}$ & & $\begin{array}{l}\text { Leptin vs fat pad } \\
\text { weight }\left(\mathbf{r}^{2}\right)\end{array}$ & $\begin{array}{l}\text { Body weight vs } \\
\text { fat pad }\left(\mathbf{r}^{2}\right)\end{array}$ \\
\cline { 2 - 2 } $\begin{array}{llll}\text { Treatment group } \\
\text { TG ON }\end{array}$ & 0.1356 & 0.4867 & 0.2311 \\
TG ON/OFF & 0.6213 & 0.5614 & 0.6699 \\
Pooled WT & 0.4462 & 0.6231 & 0.6992 \\
\hline
\end{tabular}

as treatment. TG ON females were heavier than TG ON/OFF animals, and both transgenic groups were heavier than WT animals $(44 \cdot 63 \pm 0 \cdot 29,34 \cdot 32 \pm 0 \cdot 28$ and $29 \cdot 75 \pm 0 \cdot 20 \mathrm{~g}$ respectively; $P<0 \cdot 0003)$. While weight increased with age in both the TG ON/OFF and pooled WT groups, maximum weights were achieved by TG ON females mated at 20 weeks and did not appreciably increase thereafter $(P<0 \cdot 02$; data not shown).

There was a significant interaction between treatment and age at mating for GFP weights $(P<0 \cdot 02)$. Fat pad weight at the last mating age (40 weeks) was greater for the TG ON/OFF and pooled WT animals than for TG ON females $(0.762 \pm 0.047,0.689 \pm 0.034$ and $0.382 \pm 0.059$ g respectively; $P<0 \cdot 0003)$. For the TG ON females, GFP weight was unchanged over the course of the experiment (age of mating 15-40 weeks). In contrast, GFP weight increased with advancing age for both TG ON/OFF and WT females. When GFP weight was examined as a percentage of body weight, TG ON females were leaner than TG ON/OFF animals regardless of age $(P<0.001)$ (data not shown). Furthermore, although WT females were initially leaner than TG ON/OFF animals, this difference was absent in females mated at 30 weeks of age and older. Finally, body weight and GFP weight were highly correlated with each other in all but the TG ON treatment groups (Table 2).

Plasma leptin concentrations were dependent upon treatment, age at mating $(P<0 \cdot 02)$ and interaction between the two factors $(P<0 \cdot 04)$. TG ON/OFF females had higher plasma leptin levels than pooled WT animals, and the levels of the latter were in turn greater than concentrations observed in TG ON females $(P<0 \cdot 02)$. Furthermore, leptin levels continued to increase with age in both the TG ON/OFF and pooled WT females, while they remained unchanged in TG ON mice (Fig. 1). In general, leptin levels showed energy stores to be most closely correlated with fat pad weight (overall $\left.\mathrm{r}^{2}=0 \cdot 6281\right)$ rather than body weight $\left(\mathrm{r}^{2}=0 \cdot 0641\right)$ across all treatments.

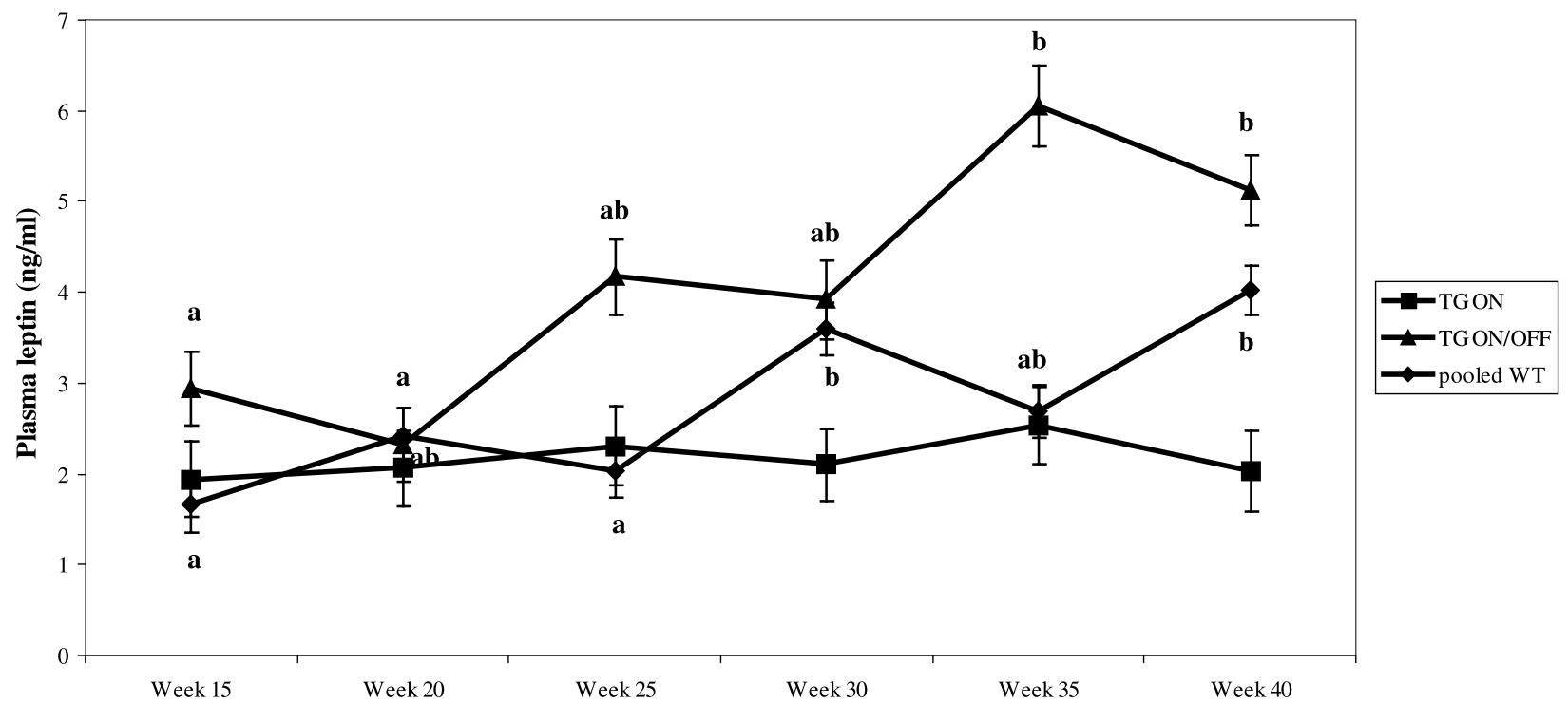

Age at mating

Figure 1 Plasma leptin concentrations for oMt1a-oGH transgenic females expressing the transgene chronically (TG ON) or from 3-8 weeks of age (TG ON/OFF) and pooled wild-type (WT) females mated at either 15, 20, 25, 30, 35 or 40 weeks of age. Values are means \pm S.E.M. Bars within treatments with different superscripts are significantly different $(P<0 \cdot 04)$. 
Table 3 Estrous cycle characteristics observed in infertile transgenic females expressing the transgene from 3 weeks of age (TG ON) or from 3-8 weeks of age (TG ON/OFF) and infertile wild-type (WT) animals. Females were assessed for estrous cyclicity by vaginal saline lavage for 14 days

\begin{tabular}{|c|c|c|c|c|c|c|c|}
\hline & $\begin{array}{l}\text { No. } \\
\text { females }\end{array}$ & $\begin{array}{l}\text { No. infertile } \\
\text { females }\end{array}$ & $\begin{array}{l}\text { Estrus-metestrus } \\
\text { recycling }\end{array}$ & $\begin{array}{l}\text { Constant } \\
\text { diestrus }\end{array}$ & $\begin{array}{l}\text { Metestrus-diestrus } \\
\text { recycling }\end{array}$ & $\begin{array}{l}\text { Normal } \\
\text { estrous cycle }\end{array}$ & $\begin{array}{l}\text { Constant } \\
\text { metestrus }\end{array}$ \\
\hline \multicolumn{8}{|l|}{ Treatment } \\
\hline TG ON & 170 & 97 & 30 & 6 & 5 & 54 & 0 \\
\hline Pooled WT & 367 & 43 & 12 & 1 & 2 & 22 & 3 \\
\hline
\end{tabular}

Numbers refer to the number of females exhibiting this estrous cycle characteristic.

When treatment groups were examined individually, GFP weight was the best predictor of plasma leptin concentrations except in the TG ON/OFF females, where body weight was more correlated with leptin $\left(\mathrm{r}^{2}=0 \cdot 6213\right)$ than fat pad weight $\left(\mathrm{r}^{2}=0.5614\right)$ (Table 2). Thus, animals with a greater proportion of body fat had higher circulating leptin levels.

Reproduction The percentage of females mating did not differ between treatment groups $(P>0 \cdot 22)$, although the number of copulatory plugs recorded did. During the 14-day period of housing females with males, TG ON females exhibited more copulatory plugs than WT females $(P<0 \cdot 01)$, although plug number was not different between the two TG groups $(1 \cdot 25,1.14$ and 1.07 plugs for TG ON, TG ON/OFF and pooled WT females respectively). Females failing to establish pregnancy continued to cycle and rebreed, as more copulatory plugs $(P<0.003)$ were observed in animals classified as infertile (data not shown). Those females that failed to mate or maintain a pregnancy to term displayed a variety of estrous cycle abnormalities (Table 3). The most common estrous cycle irregularity was cycling between estrus and metestrus.

The percentage of pregnant females was significantly reduced in TG ON females when compared with other treatment groups $(P<0 \cdot 0003)$, although the pregnancy rate improved for TG ON females as they aged. That was not the case for TG ON/OFF or WT females $(P<0 \cdot 03)$ (Fig. 2). Of note was that $11 \mathrm{TG}$ and seven WT females were found to be pregnant upon dissection, despite the fact that many of them had produced pups during the week prior to death or had exhibited no prior signs of parturition. In nearly all of these cases, a reabsorbing fetus was found to be blocking the birth canal. These 18 females were included in the pregnancy analysis, but excluded from the other reproductive statistics. In addition to transgene activation status, fertility was also correlated with plasma leptin concentrations. Lower plasma leptin levels were detected for fertile than infertile females in the TG ON and TG ON/OFF transgenic groups $(P<0 \cdot 0001)$ and in WT ON/OFF $(P<0 \cdot 05)$ females (Table 4$)$. This correlated with the infertile females having larger fat masses in these three treatment groups.

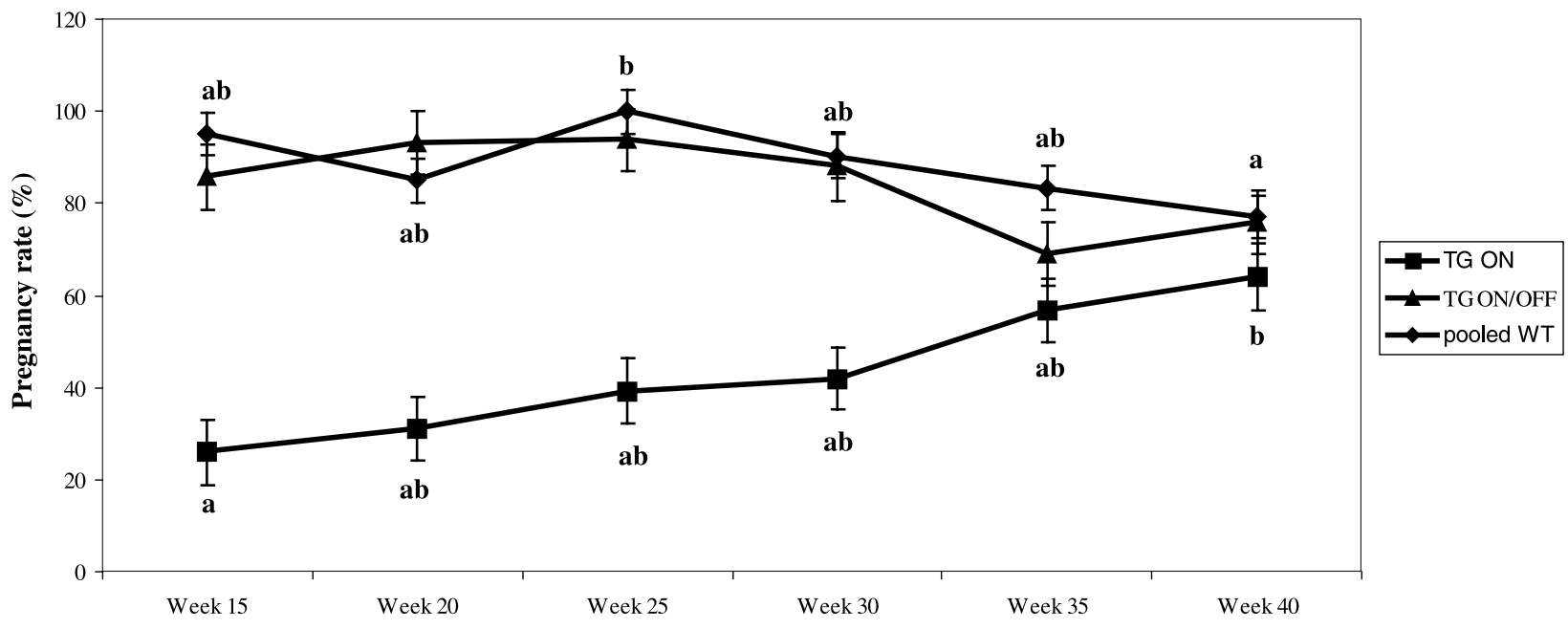

Age at mating

Figure 2 Pregnancy rate of oMt1a-oGH transgenic and WT female mice mated at 15, 20, 25, 30, 35 or 40 weeks of age. Values are means \pm S.E.M. Different superscripts within treatment groups designate statistical differences $(P<0 \cdot 03)$. 
Table 4 Plasma leptin concentrations $(\mathrm{ng} / \mathrm{ml})$ presented as means \pm S.E.M. in fertile and not pregnant oMt1a-oGH transgenic and wild-type female mice

\begin{tabular}{|c|c|c|c|c|}
\hline & TG ON & TG ON/OFF & WT ON/OFF & WT OFF \\
\hline \multicolumn{5}{|c|}{ Plasma leptin (ng/ml) } \\
\hline Fertile & $1 \cdot 57 \pm 0 \cdot 17^{a}$ & $3 \cdot 67 \pm 0 \cdot 25^{\mathrm{a}}$ & $2 \cdot 64 \pm 0 \cdot 19^{c}$ & $2 \cdot 74 \pm 0 \cdot 19$ \\
\hline Infertile & $2 \cdot 60 \pm 0 \cdot 14^{b}$ & $6 \cdot 38 \pm 0 \cdot 56^{\mathrm{b}}$ & $3 \cdot 82 \pm 0.55^{d}$ & $3 \cdot 31 \pm 0 \cdot 51$ \\
\hline
\end{tabular}

Gestation length was dependent upon both treatment group and age at mating, but there was no significant interaction between the terms $(P>0 \cdot 39)$. TG ON females had a longer gestation length than WT animals $(P<0 \cdot 05)$ $(20 \cdot 01 \pm 0 \cdot 10,19 \cdot 84 \pm 0 \cdot 07$ and $19 \cdot 75 \pm 0 \cdot 05$ days for TG ON, TG ON/OFF and pooled WT females respectively), and gestation length increased as the age of the dam advanced $(P<0 \cdot 05)$ (Table 5$)$. In addition, females produced fewer live $(P<0 \cdot 05)$ and more dead $(P<0 \cdot 01)$ pups with increasing age (Table 5$)$. Transgenic groups produced more dead offspring than the pooled WT animals $(P<0.003 ; 1.22 \pm 0.13,0.91 \pm 0.09$ and $0.33 \pm 0.06$ dead produced by TG ON, TG ON/OFF and pooled WT females respectively).

\section{Experiment 2}

Real-time TaqMan PCR Real-time PCR results showed an increase in hypothalamic NPY transcription in infertile relative to fertile animals $(P<0 \cdot 04)$. Upon further examination, this relative elevation of transcription was due to increased message in nonfertile transgenic females when compared with fertile WT animals $(P<0 \cdot 05)$ (Fig. 3). NPY transcription did not differ significantly between fertile and nonfertile animals within treatment groups $(P>0 \cdot 23)$, nor was it significantly different when examined as a function of age within groups $(P>0 \cdot 40$; data not shown).

Table 5 Gestation data for oGH transgenic and wild-type mice presented as means \pm S.E.M. Statistical comparisons are made within columns and between age groups

\begin{tabular}{|c|c|c|c|}
\hline & $\begin{array}{l}\text { Gestation length } \\
\text { (days) }\end{array}$ & $\begin{array}{l}\text { No. live } \\
\text { offspring }\end{array}$ & $\begin{array}{l}\text { No. dead } \\
\text { offspring }\end{array}$ \\
\hline \multicolumn{4}{|c|}{$\begin{array}{l}\text { Age at mating } \\
\text { (weeks) }\end{array}$} \\
\hline 15 & $19 \cdot 27 \pm 0 \cdot 13^{a}$ & $8 \cdot 91 \pm 0 \cdot 38^{a}$ & $0 \cdot 427 \pm 0 \cdot 157^{a}$ \\
\hline 20 & $19 \cdot 46 \pm 0 \cdot 11^{a}$ & $8 \cdot 16 \pm 0 \cdot 35^{a}$ & $0 \cdot 589 \pm 0 \cdot 143^{a}$ \\
\hline 25 & $19 \cdot 66 \pm 0 \cdot 10^{a}$ & $7 \cdot 54 \pm 0 \cdot 32^{\mathrm{ab}}$ & $0 \cdot 499 \pm 0 \cdot 132^{\mathrm{a}}$ \\
\hline 30 & $20 \cdot 09 \pm 0 \cdot 10^{b}$ & $6 \cdot 36 \pm 0 \cdot 32^{b}$ & $0 \cdot 765 \pm 0 \cdot 131^{\mathrm{ab}}$ \\
\hline 35 & $20 \cdot 26 \pm 0 \cdot 10^{b}$ & $5 \cdot 70 \pm 0 \cdot 33^{b c}$ & $1 \cdot 285 \pm 0 \cdot 134^{b}$ \\
\hline 40 & $20 \cdot 46 \pm 0 \cdot 10^{b}$ & $4 \cdot 85 \pm 0 \cdot 32^{c}$ & $1 \cdot 158 \pm 0 \cdot 132^{\mathrm{ab}}$ \\
\hline
\end{tabular}

Values within columns with different superscripts are significantly different from each other.
The real-time PCR results for GnRH transcription were inconclusive. Although the means were similar between fertile and nonfertile females $(P>0.95)$, the resulting large standard errors were so large as to prevent any meaningful comparisons.

In situ hybridization The NPY in situ results confirmed the real-time PCR data. In the hypothalamus, NPY expression was confined to the arcuate nucleus. Arcuate hybridization was specific, as the signal disappeared with the addition of excess unlabeled oligonucleotide to the radiolabeled probe mixture. Hybridization to the arcuate nucleus was greater in infertile oMt1a-oGH transgenic females $(n=4)$ (average hybridization area $=1.29 \times$ $10^{-2} \mathrm{~mm}^{2}$ ) than in fertile WT animals $(n=2)$ (average hybridization area $=1.27 \times 10^{-2} \mathrm{~mm}^{2}$ ) (Fig. 4), although this difference did not achieve statistical significance, probably because of the small number of animals in this experiment.

As in the real-time PCR results, GnRH hybridization was much more difficult to identify in the preoptic area, and given the small number of animals analyzed, meaningful results could not be obtained (data not shown).

\section{Discussion}

The purpose of these experiments was to characterize elevated circulating $\mathrm{GH}$ as it affected body composition and reproductive performance. More specifically, they aimed to document the changes in leptin concentrations induced by transgene expression, and to demonstrate a relationship between these differences and fertility. In addition, hypothalamic NPY expression was assessed as a possible intermediary molecule involved in transducing some of the effects of leptin and GH on the reproductive endocrine axis.

This study confirms previous reports of $\mathrm{GH}$-induced changes in body composition in oMt1a-oGH mice (Pomp et al. 1992, Thomas et al. 2001). The lean phenotype of the TG ON mice is the result of improved feed efficiency and increased lean tissue deposition (Pomp et al. 1992). The development of obesity in TG ON/OFF mice is also in agreement with previous work from our laboratory (Pomp et al. 1996, Oberbauer et al. 1997, Oberbauer \& Murray 


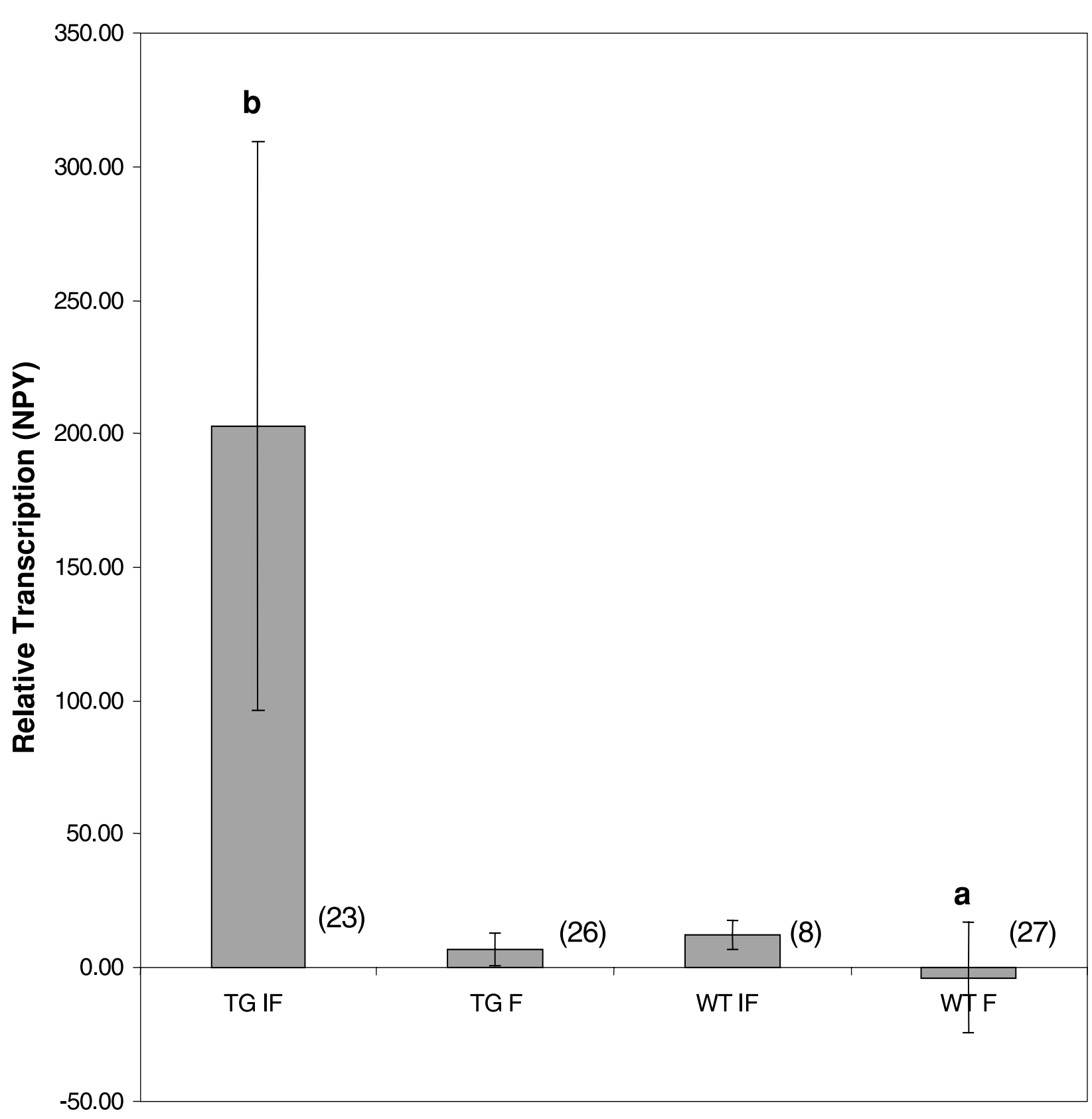

\section{Treatment}

Figure 3 Neuropeptide $\mathrm{Y}$ (NPY) gene expression in fertile (F) and infertile (IF) oMt1a-oGH transgenic (TG) and WT mice. Transcription is relative to WT F animals. Unlike superscripts are different $(P<0 \cdot 05)$. Numbers in parentheses indicate number of animals in each treatment.

1998). GH early in development, that is, beginning at 3 weeks of age, stimulates differentiation and proliferation of preadipocytes, resulting in more adipocytes in oMt1a-oGH than WT animals (Oberbauer et al. 1997, Oberbauer \& Murray 1998). Once the GH transgene stimulus is removed, filling of adipocytes occurs, promoting adipose deposition and subsequent obesity (Oberbauer et al. 1997, Oberbauer \& Murray 1998). TG ON/OFF mice possessed higher circulating leptin levels than did TG ON mice, reflecting the elevated fat mass in animals of this treatment group. The close correlation between plasma leptin concentration and fat 
(a)

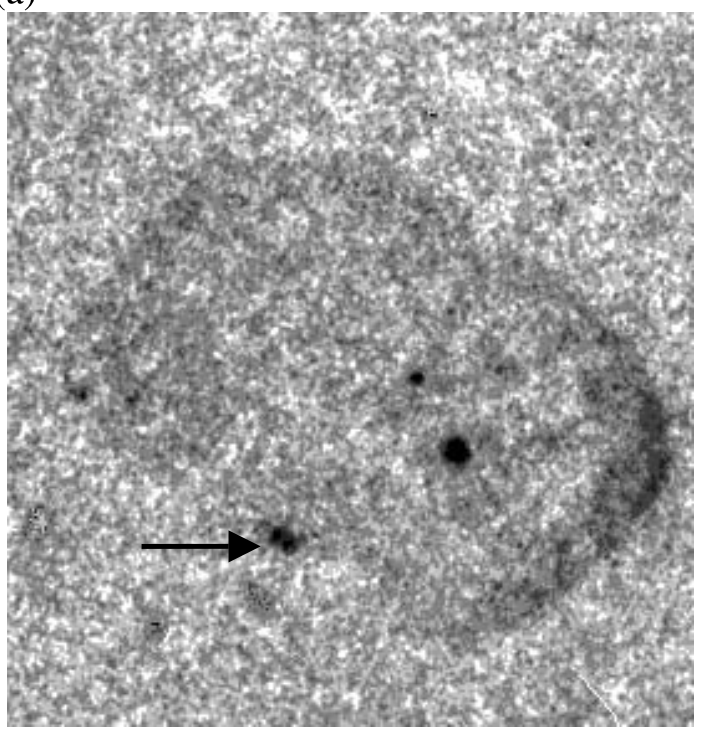

(b)

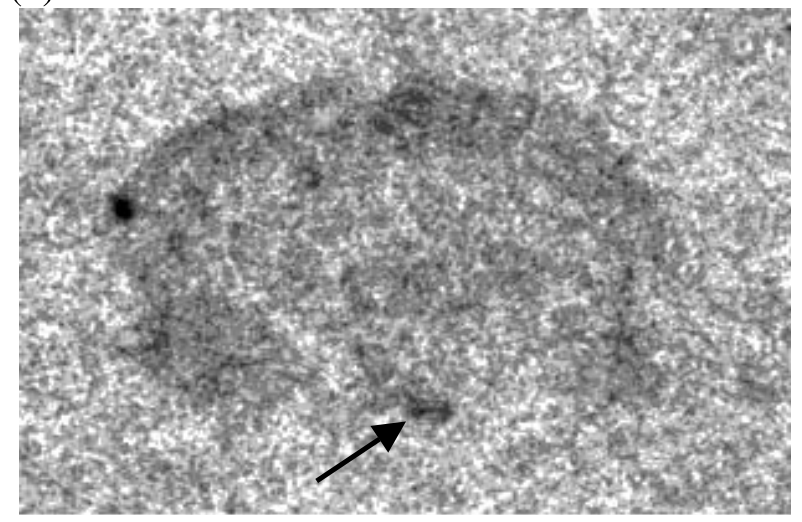

Figure 4 Neuropeptide $Y$ expression in the hypothalamus of (a) an infertile oMt1a-oGH transgenic mouse and (b) a fertile WT cohort. Arrows indicate specific hybridization to the arcuate nucleus. Localization of mRNA expression was performed on $14 \mu \mathrm{m}$ coronal sections hybridized with ${ }^{33} \mathrm{P}$-labeled oligonucleotide probe.

mass has been documented elsewhere as well (Rosenbaum et al. 1996).

Infertile TG ON animals exhibited more copulatory plugs than did fertile counterparts, indicating that these females are unable to establish pregnancy, and thus continue to cycle and remate. While this suggests inadequate prolactin secretion after the mating stimulus, prolactin supplementation in these mice does not improve pregnancy rates (Pomp et al. 1995). Estrous cycle length is not different between TG and WT treatment groups (Thomas et al. 2001), although over $40 \%$ of the infertile TG ON females in this experiment exhibited irregular estrous cycling, which was also present to a lesser degree in WT mice. Menstrual abnormalities are common in acromegalic women (Jadresic et al. 1982), and transgenic mice expressing bovine or human $\mathrm{GH}$ constructs often demonstrate alterations in gonadotropin secretion (Chandrashekar et al. 1992, Chandrashekar \& Bartke 1993, Tang et al. 1993), implying that 'excess' circulating GH alters gonadotropin secretion, leading to an abnormal reproductive cycle. However, since gonadotropin concentrations were not measured in oMt1a-oGH mice, we are unable to confirm or refute this concept at this time. Alternatively, reproductive aging may also have contributed to the reduced reproductive performance documented here. Vaginal smears with either chronic cornification or leukocytic cells are indicative of declining reproductive function (Nelson et al. 1982). However, it seems unlikely that reproductive aging is a major cause of infertility in transgenic animals, as a majority of the infertile transgenic females did not display a constant presence of vaginal cornification or leukocytic cells. In addition, reproductive aging in rodents is associated with reduced hypothalamic NPY message (Sahu et al. 1988, Chua et al. 1991, Sahu \& Kalra 1998), which was not observed in this study. NPY concentrations did not vary by age within treatment groups, and infertility was associated with an increase, rather than a decrease, in NPY expression.

The reduced pregnancy rate in TG ON animals is in agreement with observations from other $\mathrm{GH}$ transgenic mouse lines (Cecim et al. 1995) and may be a result of reduced leptin signaling. Yu et al. (1997) observed that low leptin concentrations $\left(10^{-10}\right.$ and $\left.10^{-12}\right)$ stimulated GnRH release from hypothalamic explants of adult male rats, but higher concentrations of leptin significantly depressed GnRH. Baskin et al. (1998) hypothesized that binding of leptin to its receptor at the surface of the arcuate nucleus may in fact result in downregulation of receptor transcription and reduce leptin signaling capacity. Leptin administration, in the presence of adrenal steroids, activates leptin receptor $(\mathrm{Ob} \mathrm{Rb})$ signal transduction and subsequent STAT-3 phosphorylation, which stimulates transcription of SOCS-3. SOCS-3 expression then negatively regulates leptin signal transduction by downregulation of the JAK-STAT pathway (Bjorbaek et al. 1999, Madiehe et al. 2001, Wang \& Campbell 2002). In addition, both GH (Ram \& Waxman 2000) and glucocorticoids (Madiehe et al. 2001), which are also elevated in oMt1a-oGH females actively expressing the transgene (Thomas et al. 2001), are also capable of activating members of the SOCS family to reduce cytokine signaling.

NPY is important for generation of the GnRH surge during proestrus (Bauer-Dantoin et al. 1992, Besecke \& Levine 1994, Khorram et al. 1998), although chronically elevated NPY expression inhibits reproductive function (Pierroz et al. 1995) through suppression of $\mathrm{GnRH}$ secretion (Catzeflis et al. 1993). Leptin attenuates NPY expression both in vitro ( $\mathrm{Yu}$ et al. 1997) and in vivo 
(Schwartz et al. 1996), although in animals with relatively elevated leptin concentrations, leptin may be less able to downregulate NPY expression due to reduced signaling capacity, resulting in suppression of GnRH and reduced reproductive competence. This is in agreement with the elevated circulating leptin concentrations and NPY expression observed in the hypothalami of infertile transgenic females. Because our GnRH data were inconclusive, we were unable to determine how changes in NPY expression would affect GnRH message. However, elevated hypothalamic NPY expression and reduced reproductive performance suggest alterations in the hypothalamic-pituitary-ovarian axis.

Previous studies in our laboratory have documented a reduced pregnancy rate in TG ON/OFF females (Thomas et al. 2001), which was not seen here. This is surprising, as obesity is associated with menstrual abnormalities (Rogers \& Mitchell 1952, Hartz et al. 1979, Bray et al. 1997) and pregnancy complications (Kalkhoff 1992) in women. Furthermore, hyperleptinemia and adiposity are negatively correlated with gonadotropin secretion in pubertal girls (Bouvattier et al. 1998). However, the TG ON/OFF females used in the Thomas et al. (2001) study were examined immediately following transgene inactivation, and residual GH effects may have contributed to the reduced fertility observed. In addition, the differences in body composition and plasma leptin concentrations in animals between GH treatment groups are not pronounced until later in life (this study). In this report, infertile TG ON, TG ON/OFF and WT ON/OFF animals displayed significantly elevated plasma leptin levels compared with fertile counterparts, a finding reflective of a larger fat mass.

The increased interval required by TG ON females to generate pups may be in part due to a reduced ability of the reproductive tract to support fetal development. Transgenic females are often observed to have small uterine horns; in addition, many are avascular, even after pregnancy (A Thomas, personal observation). Although TG ON females displayed the longest gestation length, litter size was not different between treatment groups, in agreement with previous studies from our laboratory (Murray \& Pomp 1995, Pomp et al. 1995, Thomas et al. 2001). Pomp et al. (1995) reported lower average pup weights for transgenic mice when compared with WT controls. In a similar study using mice expressing a variety of GH constructs, Naar et al. (1991) observed that fetal size was a function of maternal genotype, not fetal genotype. The combination of increasing numbers of dead and reduced numbers of live offspring with increasing age of the dam may be due to poor maternal behavior. Both failure to feed pups and cannabalism are common problems among oMt1a-oGH transgenic mothers (A Thomas, personal observation).

Previous reports have characterized the reproductive deficits in oMt1a-oGH transgenic mice (Murray \& Pomp
1995, Pomp et al. 1995, Thomas et al. 2001), although the mechanisms by which GH suppresses fertility have remained elusive. In this study, chronic expression of the oMt1a-oGH transgene resulted in decreased reproductive performance, and elevated leptin levels were associated with infertility in transgenic females with chronically elevated GH levels. This suggests that, in addition to high $\mathrm{GH}$ concentrations, elevated circulating levels of leptin also contribute to the reduction in fertility observed in oGH transgenic females, especially in those animals with increased adipose accrual. High circulating concentrations of leptin may reduce leptin receptor signaling due to induction of SOCS-3 transcription, resulting in a reduced ability of leptin to downregulate NPY expression and subsequent suppression of reproductive performance.

\section{References}

Baskin DG, Seeley RJ, Juijper JL, Lok S, Weigle DS, Erickson JC, Palmiter RD \& Schwartz MW 1998 Increased expression of MRNA for the long form of the leptin receptor in the hypothalamus is associated with leptin hypersensitivity and fasting. Diabetes 47 538-543.

Bauer-Dantoin AC, McDonald JK \& Levine JE 1992 Neuropeptide Y potentiates luteinizing hormone (LH)-releasing hormone-induced LH secretion only under conditions leading to preovulatory LH surges. Endocrinology 131 2946-2952.

Besecke LM \& Levine JE 1994 Acute increase in responsiveness of luteinizing hormone (LH)-releasing hormone nerve terminals to neuropeptide-Y stimulation before the preovulatory LH surge. Endocrinology 135 63-66.

Bjorbaek C, Elmquist JK, El-Haschimi K, Kelly J, Ahima RS, Hileman S \& Flier JS 1999 Activation of SOCS-3 messenger ribonucleic acid in the hypothalamus by ciliary neurotrophic factor. Endocrinology 140 2035-2043.

Bouvattier C, Lahlou N, Roger M \& Bougnères P 1998 Hyperleptinaemia is associated with impaired gonadotrophin response to GnRH during late puberty in obese girls, not boys. European Journal of Endocrinology 138 653-658.

Bray GA 1997 Obesity and reproduction. Human Reproduction 12 (suppl 1) 26-32.

Brzechffa PR, Jakimiuk AJ, Agarwal SK, Weitsman SR, Buyalos RP \& Magoffin DA 1996 Serum immunoreactive leptin concentrations in women with polycystic ovary syndrome. Journal of Clinical Endocrinology and Metabolism 81 -4169.

Buskirk DD, Faulkner DB, Hurley WL, Kesler DJ, Ireland FA, Nash TG, Castree JC \& Vicini JL 1996 Growth, reproductive performance, mammary development and milk production of beef heifers as influenced by prepubertal dietary energy and administration of bovine somatotropin. Journal of Animal Science $\mathbf{7 4}$ 2649-2662.

Campfield LA, Smith FJ \& Burn P 1996 The ob protein (leptin) pathway - a link between adipose tissue mass and central neural networks. Hormone Metabolism Research 28 619-632.

Campfield LA, Smith FJ, Guisez Y, Devos R \& Burn P 1995 Recombinant mouse OB protein: evidence for a peripheral signal linking adiposity and central neural networks. Science $\mathbf{2 6 9}$ 546-549.

Catzeflis C, Pierroz DD, Rohner-Jeanrenaud F, Rivier JE, Sizonenko PC \& Aubert ML 1993 Neuropeptide Y administered chronically into the lateral ventricle profoundly inhibits both the gonadotropic and the somatotropic axis in intact adult female rats. Endocrinology 132 224-234. 
Cecim M, Kerr J \& Bartke A 1995 Effects of bovine growth hormone (bGH) transgene expression or bGH treatment on reproductive functions in female mice. Biology of Reproduction 52 1144-1148.

Chandrashekar V \& Bartke A 1993 Effects of age and endogenously secreted human growth hormone on the regulation of gonadotropin secretion in female and male transgenic mice expressing the human growth hormone gene. Endocrinology 132 1482-1488.

Chandrashekar V, Bartke A \& Wagner TE 1992 Neuroendocrine function in adult female transgenic mice expressing the human growth hormone gene. Endocrinology 130 1802-1808.

Chapula W, Vechiarelli B, Galligan DT, Ferguson JD, Baird LS, Hemken RW, Harmon RJ, Soderholm CG, Otterby DE, Annexstad RJ et al. 1996 Responses of dairy cows supplemented with somatotropin during weeks 5 through 43 of lactation. Journal of Dairy Science 79 800-812.

Chua SC Jr., Leibel RL \& Hirsch J 1991 Food deprivation and age modulate neuropeptide gene expression in the murine hypothalamus and adrenal gland. Molecular Brain Research 9 95-101.

Cintra A, Fuxe K, Solfrini V, Agnati LF, Tinner B, Wikstrom AC, Staines W, Okret S \& Gustafsson JA 1991 Central peptidergic neurons as targets for glucocorticoid action. Evidence for the presence of glucocorticoid receptor immunoreactivity in various types of classes of peptidergic neurons. Journal of Steroid Biochemistry and Molecular Biology 40 93-103.

Downer JV, Patterson DL, Rock DW, Chapula WV, Cleale RM, Firkins JL, Lynch GL, Clark JH, Brodie BO, Jenny BF et al. 1993 Dose titration of sustained-release recombinant bovine somatotropin in lactating dairy cows. Journal of Dairy Science 76 1125-1136.

Eisen EJ \& Leatherwood JM 1981 Predicting percent fat in mice. Growth 45 100-107.

Esteban E, Kass PH, Weaver LD, Rowe JD, Holmber CA, Franti CE \& Troutt HF 1994 Reproductive performance in high producing dairy cows treated with recombinant bovine somatotropin. Journal of Dairy Science 77 3371-3381.

Frederich RC, Hamann A, Anderson S, Lollmann B, Lowell BB \& Flier JS 1995 Leptin levels reflect body lipid content in mice: evidence for diet-induced resistance to leptin action. Nature Medicine 1 1311-1314.

Fueshko SM, Key S \& Wray S 1998 Luteinizing hormone releasing hormone (LHRH) neurons maintained in nasal explants decrease LHRH messenger ribonucleic acid levels after activation of GABA(A) receptors. Endocrinology 139 2734-2740.

Guan X-M, Yu H \& Van der Ploeg LHT 1998 Evidence of altered hypothalamic pro-opiomelanocortin / neuropeptide Y mRNA expression in tubby mice. Brain Research. Molecular Brain Research 59 273-279.

Halaas JL, Boozer C, Blair-West J, Fidahusein N, Denton DA \& Friedman JM 1997 Physiological response to long-term peripheral and central leptin infusion in lean and obese mice. PNAS 94 8878-8883.

Hartz AJ, Barboriak PN, Wong A, Katayama KP \& Rimm AA 1979 The association of obesity with infertility and related menstrual abnormalities in women. International Journal of Obesity 3 57-73.

Jacobs HS \& Conway GS 1999 Leptin, polycystic ovaries and polycystic ovary syndrome. Human Reproduction Update 5 166-171.

Jadresic A, Banks LM, Ghild DF, Diamant L, Doyle FH, Fraser TR \& Joplin GF 1982 The acromegaly syndrome. Quarterly Journal of Medicine 202 189-204.

Kalkhoff RK 1992 Obesity in pregnancy. In: Obesity, pp 550-562. Eds P Björntorp \& BN Brodoff. Philadelphia: J.B. Lippincott Co.

Khorram O, Pau K-Y F \& Spies HG 1998 Release of hypothalamic neuropeptide $\mathrm{Y}$ and effects of exogenous NPY on the release of hypothalamic GnRH and pituitary gonadotropins in intact and ovariectomized does in vitro. Peptides 9 411-417.

McGuffey RK, Basson RP, Snyder DL, Block E, Harrison JH, Rakes AH, Emery RS \& Muller LD 1991 Effect of somidobove sustained release administration on the lactation performance of dairy cows. Journal of Dairy Science 74 1263-1276.
Madiehe AM, Lin L, White C, Braymer HD, Bray GA \& York DA 2001 Constitutive activation of STAT-3 and downregulation of SOCS-3 expression induced by adrenalectomy. American Journal of Physiology, Regulatory Integrative Comparative Physiology 281 R2048-R2058.

Misaki N, Higuchi H, Yamagata K \& Miki N 1992 Identification of glucocorticoid responsive elements (GREs) at far upstream of rat NPY gene. Neurochemistry International 21 185-189.

Montemurro DG \& Dukelow RH 1972 A stereotaxic atlas of the diencephalon and related structures of the mouse. New York: Futura Publishing Company.

Moore DD, Marks AR, Buckley DI, Kapler G, Payvar F \& Goodman HM 1985 The first intron of the human growth hormone gene contains a binding site for glucocorticoid receptor. PNAS $\mathbf{8 2}$ 699-702.

Murray JD \& Pomp D 1995 Interaction between reproductive performance and dietary energy levels fed to female oMt1a-oGH transgenic mice. Transgenics 1 553-563.

Nelson JF, Felicio LS, Randall PK, Sims C \& Finch CB 1982 A longitudinal study of estrous cyclicity in aging C57BL/6J mice: I. Cycle frequency, length and vaginal cytology. Biology of Reproduction 27 327-339.

Oberbauer AM \& Murray JD 1998 Consequences of limited exposure to elevated growth hormone in the mature oMt1a-oGH transgenic mouse. Growth, Development and Aging 62 87-93.

Oberbauer AM, Runstadler JA, Havel PJ \& Murray JD 2001 Obesity and elevated plasma leptin concentration in oMt1a-oGRowth hormone transgenic mice. Obesity Research 9 51-58.

Oberbauer AM, Stern JS, Johnson PR, Horowitz BA, German JB, Phinney SD, Beermann DH, Pomp D \& Murray JD 1997 Body composition of inactivated growth hormone (oMt1a-oGH) transgenic mice: generation of an obese phenotype. Growth, Development and Aging 61 169-179.

Oldenbroek JK, Garssen GJ, Jonker LJ \& Wilkinson JID 1993 Effects of treatment of dairy cows with recombinant bovine somatotropin over three or four lactations. Journal of Dairy Science 76 453-467.

Orian JM, Lee CS, Weiss LM \& Brandon MR 1989 The expression of a metallothionein-ovine growth hormone fusion gene in transgenic mice does not impair fertility but results in pathological lesions in the liver. Endocrinology 124 455-463.

Palmiter RD, Norstedt G, Gelinas RE, Hammer RE \& Brinster RL 1983 Metallothionein-human GH fusion genes stimulate growth of mice. Science 222 809-814.

Pierroz DD, Gruaz NM, d'Allè ves V \& Aubert ML 1995 Chronic administration of neuropeptide $\mathrm{Y}$ into the lateral ventricle starting at 30 days of life delays sexual maturation in the female rat. Neuroendocrinology 61 293-300.

Pomp D, Geisert RD, Durham CM \& Murray JD 1995 Rescue of pregnancy and maintenance of corpora lutea in infertile transgenic mice expressing an ovine metallothionein 1a-ovine growth hormone fusion gene. Biology of Reproduction 51 170-178.

Pomp D, Nancarrow CD, Ward KA \& Murray JD 1992 Growth, feed efficiency and body composition of transgenic mice expressing a sheep metallothionein 1a-sheep growth hormone fusion gene. Livestock Production Science 31 335-350.

Pomp D, Oberbauer AM \& Murray JD 1996 Development of obesity following inactivation of a growth hormone transgene in mice. Transgenic Research 5 13-23.

Ram PA \& Waxman DJ 2000 Role of the cytokine-inducible $\mathrm{SH} 2$ protein CIS in desensitization of STAT5b signaling by continuous growth hormone. Journal of Biological Chemistry 275 39487-39496.

Rogers J \& Mitchell GW Jr. 1952 The relation of obesity to menstrual disturbances. New England Journal of Medicine 247 53-55.

Rogers P \& Webb GP 1980 Estimation of body fat in normal and obese mice. British Journal of Nutrition 43 83-86.

Rosenbaum M, Nicolson M, Hirsch J, Heymsfield SB, Gallagher D, Chu F \& Leibel RL 1996 Effects of gender, body composition, and 
menopause on plasma concentrations of leptin. Journal of Clinical Endocrinology and Metabolism 81 3424-3427.

Sahu A \& Kalra SP 1998 Absence of increased neuropeptide Y neuronal activity before and during the luteinizing hormone $(\mathrm{LH})$ surge may underlie the attenuated preovulatory LH surge in middle-aged rats. Endocrinology 139 696-702.

Sahu A, Kalra PS, Crowley WR \& Kalra SP 1988 Evidence that hypothalamic neuropeptide $\mathrm{Y}$ secretion decreases in aged male rats: implications for reproductive aging. Endocrinology 122 199-203.

Schwartz MW, Baskin DG, Bukowski TR, Kuijper JL, Foster D, Lasser G, Prunkard DE, Porte D Jr., Woods SC, Seeley RJ \& Weigle DS 1996 Specificity of leptin action on elevated blood glucose levels and hypothalamic neuropeptide Y gene expression in ob/ob mice. Diabetes 45 531-535.

Shanahan CM, Rigby NW, Murray JD, Marshall JT, Townrow CA, Nancarrow CD \& Ward KA 1989 Regulation of expression of a sheep metallothionein 1a-sheep growth hormone fusion gene in transgenic mice. Molecular and Cellular Biology 9 5473-5479.

Sinha MK \& Caro JF 1998 Clinical aspects of leptin. Vitamins and Hormones 54 1-30.

Suzuki M, Nishihara M \& Takahashi M 1995 Hypothalamic gonadotropin-releasing hormone gene expression during rat estrous cycle. Endocrine Journal 42 789-796.

Tang K, Bartke A, Gardiner CS, Wagner TE \& Yun JS 1993

Gonadotropin secretion, synthesis, and gene expression in human growth hormone transgenic mice and in Ames dwarf mice. Endocrinology 132 2518-2524.

Thomas AD, Murray JD, Famula TR \& Oberbauer AM 2001 Growth hormone and fertility in oMt1a-oGH transgenic mice. Reproduction 122 537-544.

Wang J \& Campbell IL 2002 Cytokine signaling in the brain: putting a SOCS in it? Journal of Neuroscience Research 67 423-427.

Wisden W \& Morris BJ 1994 In situ hybridization with synthetic oligonucleotide probes. In: In situ hybridization protocols for the brain, pp 9-34. London: Academic Press, Harcourt Brace \& Company.

Yu WH, Kimura M, Walczewska A, Karanth S \& McCann SM 1997 Role of leptin in hypothalamic-pituitary function. PNAS $\mathbf{9 4}$ 1023-1028.

Zeman W \& Innes JRM 1963 Craigie's neuroanatomy of the rat, p 119. New York: Academic Press.

Zhang Y, Proenca R, Maffei M, Barone M, Leopold L \& Friedman JM 1994 Positional cloning of the mouse obese gene and its human homologue. Nature 372 425-432.

Received 11 May 2004

Accepted 27 May 2004

Made available online as an

Accepted Preprint 4 June 2004 